\title{
Basal Ganglia Infarct in an Infant with Sickle Cell Disease - A Rare Association
}

Smita Mahapatra ${ }^{1 *}$, Sitaram Mahapatra ${ }^{1}$, Sudha Sethy², Rupa Das ${ }^{1}$, Pranati Mohanty ${ }^{1}$ and Kalyani Hazra ${ }^{1}$

${ }^{1}$ Department of Pathology, S.C.B. Medical College, Cuttack, Orissa, India

${ }^{2}$ Department of Hematology, S.C.B. Medical College, Cuttack, Orissa, India

\begin{abstract}
Cerebrovascular accidents are common in elderly people, but rare in children. The stroke developing due to basal ganglion infarct in an infant with sickle cell disease (homozygous) is extremely rare. To the best of our knowledge, not a single case has been repoted till date. We are reporting a 10 months old infant developing stroke after a mild fall. The child was diagnosed of lacunar basal ganglion infarct in MRI. No abnormality was detected in routine hematological check-up and coagulation profile. But, sickling test was positive and confirmed of Sickle Cell Disease (SCD) in Hemoglobin electrophoresis (capillary zone). Although extremely rare, while dealing with stroke in infants and children, possibility of SCD should always be kept in mind.
\end{abstract}

Keywords: Basal ganglion infarct; Sickle cell disease; Infant

\section{Introduction}

Annual average reported incidence of childhood stroke in India is 13-33/100,000/year [1]. Children with Sickle Cell Disease (SCD) are at high risk of ischemic stroke and transient ischemic attack [2]. Cerebrovascular Accident (CVA) is a leading cause of neurologic morbidity and mortality in SCD and about $12 \%$ of patients experience stroke by 21 years [3-5]. However, infants presenting with stroke is extremely rare. Overall prevalence of silent infarct/ischemia is present in $27 \%$ case [6]. We are reporting association of basal ganglion infarct and SCD which is the first case to be reported in English literature to the best of our knowledge in an infant of 10 months old.

\section{Case Report}

A 10 month male infant presented with left facial palsy and vomiting, altered sleep, seizure, after a fall from bed, about two feet from the floor. The child fell on his head, but there was no loss of consciousness. He had seizure just after the fall which was focal affecting left upper extremity. There was no history of any drug intake or bleeding from anywhere. The infant was a term baby borne normally with no congenital, neurological, cardiac or metabolic abnormalities. No abnormality was detected in general examination. Neurological examination revealed Upper Motor Neuron (UMN) type of classical hemi paresis. Both side plantar Babiski reflex was exaggerated. Deep tendon reflex of left side knee, ankle, wrist and elbow was exaggerated and normal in the right side. Left side tone was hypertonic with normal tone in right side. With $7^{\text {th }}$ cranial nerve palsy of classical UMN type there was dribbling of saliva from left side and deviation of angle of mouth to the right side. Nasolabial fold was obliterating in left side. All these features were normal in the right side. Other cranial nerves were intact. Neck rigidity was not present. In CVS no abnormality was detected with regular heart rate of $94 /$ mins, normal S1, S2 with no added sound or murmur and no cardiomegaly. MRI scan done suggested lacunar infarct involving right basal ganglion (Figure 1). Family history did not reveal any other illness predisposing to the present event. There were no thromboembolic phenomena in the parents or extended family members.

In Hematological examination, Hemoglobin found was $10.6 \mathrm{gm} /$ dL. In peripheral smear examination; Red Blood Cells (RBC) were mostly normocytic normochromic with mild anisopoikilocytosis. Few fragmented cells and sickle like cells along with occasional

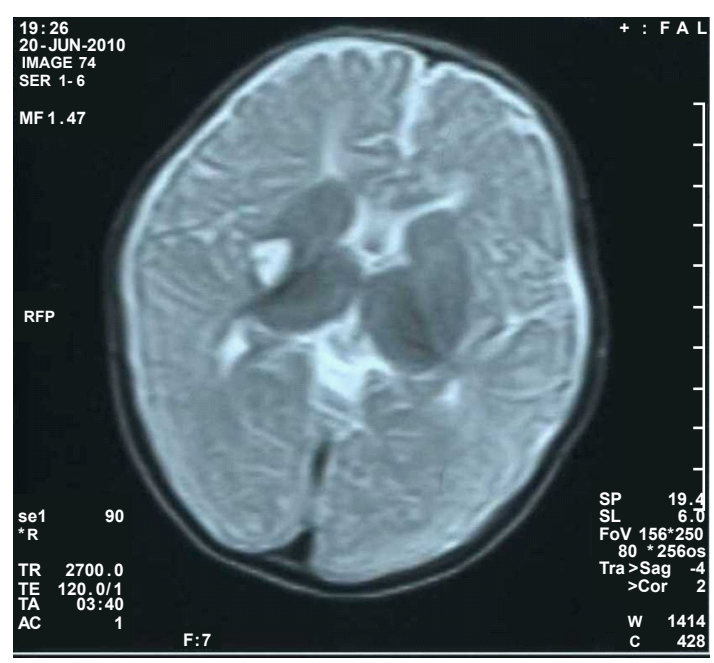

Figure 1: MRI scan showing lacunar infarct of right basal ganglion.

normoblasts were seen (Figure 2). In White Blood Cell (WBC) series Total Leukocyte Count (TLC) was $16.2 \times 10^{9} / \mathrm{L}$ and Differential Cell Count (DC) was within normal limit. No blast was seen. Total platelet count was normal with a count of $300 \times 10^{3} / \mathrm{L}$. Sickling test was positive (Figure 3). Hemoglobin electrophoresis (capillary zone) of the infant suggested SCD, HbSS (Figure 4) and both parents with sickle cell trait (HbAS). Since, the child presented for the first time and both the parents being sickle cell trait were asymptomatic, prior screening for

${ }^{*}$ Corresponding author: Dr. Smita Mahapatra, C/O- Mr. N.K. Mishra, N-1/256 I.R.C. Village, Nayapalli, Bhubaneswar, Orissa, India-751015, Tel: 91-9437094138; E-mail: doctorsmita@rediffmail.com

Received May 15, 2012; Accepted June 09, 2012; Published June 15, 2012

Citation: Mahapatra S, Mahapatra S, Sethy S, Das R, Mohanty P, et al. (2012) Basal Ganglia Infarct in an Infant with Sickle Cell Disease - A Rare Association. J Blood Disorders Transf 3:125. doi:10.4172/2155-9864.1000125

Copyright: (c) 2012 Mahapatra S, et al. This is an open-access article distributed under the terms of the Creative Commons Attribution License, which permits unrestricted use, distribution, and reproduction in any medium, provided the original author and source are credited. 


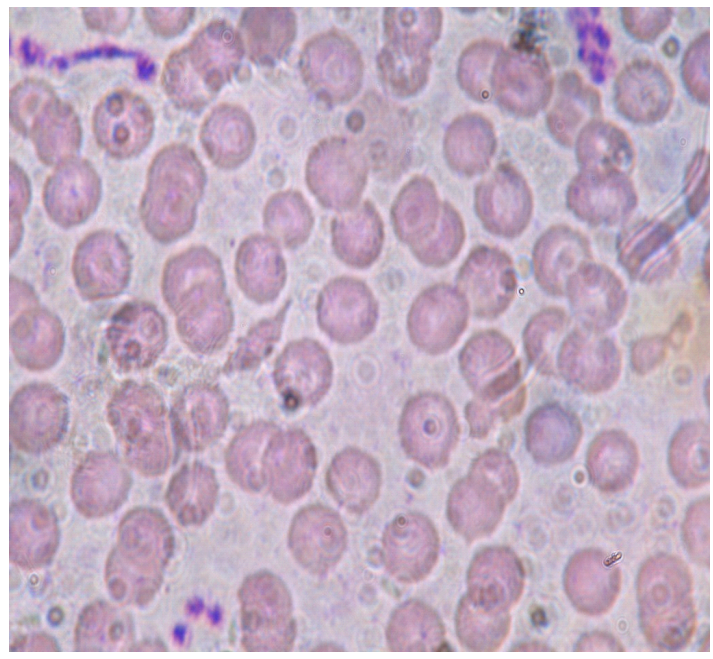

Figure 2: The peripheral blood smear is mostly normocytic normochromic with few sickle like cell (x1000, Leishman).

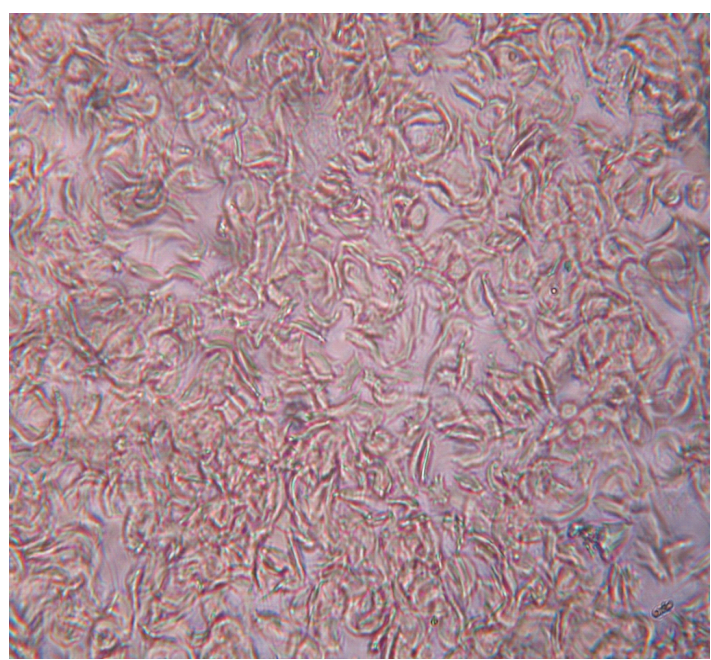

Figure 3: Irreversible sickle cells in sickling test (x400).

hemoglobinopathy was not done. In coagulation profile, PT was 12.8 secs, aPTT was 29.2 secs, and INR was 1.2 and rest of the coagulation study revealed no abnormality. The child was managed conservatively with Intravenous (IV) Dextrose saline with sodium bicarbonate, I.V. Mannitol, Epsilon along with parenteral antibiotic supplementation for 5 days. Chronic RBC or exchange blood transfusion was not required as patient recovered rapidly. With this, the baby showed marked improvement even without any anticoagulant therapy. There after the child was maintained with Folic acid one tablet daily and Hydroxyurea $200 \mathrm{mg} /$ day. The patient was followed up at regular interval and was doing well.

\section{Discussion}

Recognition of childhood stroke is difficult and challenging. Annual average reported incidence being 13-33/100,000 per year in India [1]. Cranial trauma in young children can cause ischemic infarct $[7,8]$. The causes of stroke in children are congenital or acquired heart disease, arterial dissection, Sickle Cell Disease (SCD), intracranial vasculitis,

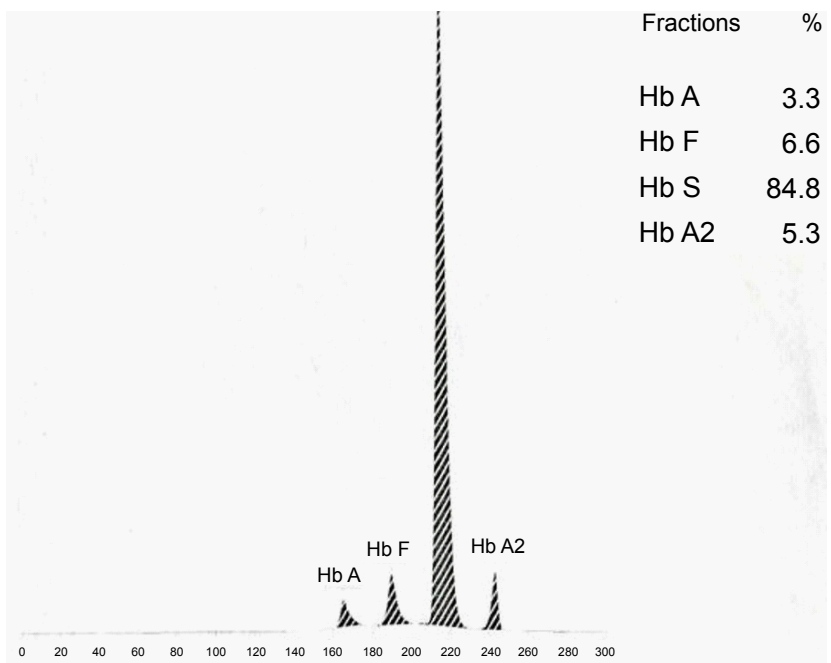

Figure 4: Hemoglobin electrophoresis (capillary zone) showing sickle cell disease.

varicella zoster infection, Moyamoya syndrome ( vasculopathy of the cranial arteries), congenital vascular lesions, thrombocytopenia, coagulation defects like Hemophilia A (factor VIII deficiency) and B (factor IX deficiency) [9]. A study of 55 patients with infarction within 6 to 14 years age group showed HbSS in 52 and HbSC in 3 cases [6]. Lesions within basal ganglion or thalamus were present in $27 \%$. Silent lesions were seen in $13 \%$ [6]. But, to the best of our knowledge, we are reporting for the first time basal ganglion infarction in an infant of 10 months old that was also diagnosed having SCD.

The pathophysiology of stroke after mild injury in young children is either thrombus or spasm of lenticulostriate branches of middle cerebral artery. These vessels are end arteries which originate from the main trunk at a more acute angle in children; forming a redundant extra cerebral segment. Any motion of brain may lead to the disruption of the arteries between the mobile extra cerebral segment and fixed intracerebral portion. This may lead to the mechanical disruption of distal blood supply or intimal trauma leading to subsequent thrombosis/spasm [10,11]. Rana et al. [12] have reported 7 cases of ischemic stroke in children of which basal ganglia were involved in 5 cases while internal capsule in 2 cases. Relative delay of symptoms in many cases can be explained on the basis of thrombus generation and immediate onset due to mechanical disruption of blood or spasm. The manifestation was immediate in our case due to the spasm of the vessel following a mild fall which led to local ischemia resulting in sickling and occlusion of the vessel which further aggravated distal segment ischemia ultimately resulting in basal ganglion infarct.

Pathophysiology of vasculopathy in SCD can be explained by hemolysis-associated low arginine and Nitric Oxide (NO) bioavailability amplified by oxidative stress, ischemia-reperfusion injury, inflammation, apolipoprotin A-1 depletion and hypercoagulable state [13]. Impaired NO bioavailability is the central feature of endothelial dysfunction leading to vasculopathy in SCD. The brains of young children with HbSS are particularly vulnerable to ischemic injury [14]. Occlusion of large and small vessels, red cell sludging, and distal field insufficiency (border-zone infarction) have lead to the pathogenesis of brain injury. This was explained in our case who was an infant of SCD 
Citation: Mahapatra S, Mahapatra S, Sethy S, Das R, Mohanty P, et al. (2012) Basal Ganglia Infarct in an Infant with Sickle Cell Disease - A Rare Association. J Blood Disorders Transf 3:125. doi:10.4172/2155-9864.1000125

developing stroke immediately after a mild fall due to the vulnerability of his brain to infarct.

Novel small molecular therapeutics targeting sickle cell vasculopathy are oral L-Arginine to increase NO level, Niacin to increase apolipoprotin A-1 and HDL level, endothelial receptors blocker, inhalation of low concentration of $\mathrm{CO}$, antihemolytic drug hydroxyurea to decrease plasma hemoglobin level and NO scavenging improving vasculopathy [15].

Although the management of many complications of SCD continues to improve, neurologic complications remain a significant problem. CVA is a leading cause of neurologic morbidity and mortality. Thus, it is highly recommended to rule out SCD in stroke patients even in infants.

\section{References}

1. Kalra V (1999) Practical Neurology. (1stedn), Arya Publication, New Delhi.

2. Kirkham FJ, DeBaun MR (2004) Stroke in Children with Sickle Cell Disease. Curr Treat Options Neurol 6: 357-375.

3. Portnoy BA, Herion JC (1972) Neurological manifestations in sickle-cell disease, with a review of the literature and emphasis on the prevalence of hemiplegia. Ann Intern Med 76: 643-652.

4. Powars D, Wilson B, Imbus C, Pegelow C, Allen J (1978) The natural history of stroke in sickle cell disease. Am J Med 65: 461-471.
5. Balkaran B, Char G, Morris JS, Thomas PW, Serjeant BE, etal. (1992) Stroke in a cohort of patients with homozygous sickle cell disease. J Pediatr 120: 360366.

6. Moser FG, Miller ST, Bello JA, Pegelow CH, Zimmerman RA, et al. (1996) The spectrum of brain MR abnormalities in sickle cell disease: a report from the Cooperative Study of Sickle Cell Disease. AJNR Am J Neuroradiol 17: 965-972.

7. Williams AN (2003) Running around in circles following ischemic stroke. Arch Dis Child 88: 743.

8. Muthukumar N (1996) Basal ganglia internal capsule low density lesions in children with mild head injury. Br J Neurosurg10: 391-393.

9. Roach ES (2000) Stroke in Children. Curr Treat Options Neurol 2: 295-304.

10. Shaffer L, Rich PM, Pohl KR, Ganesan V (2003) Can mild head injury cause ischaemic stroke? Arch Dis Child 88: 267-269.

11. Umansky F, Gomes FB, Dujovny M, Diaz FG, Ausman Jl, et al. (1985) The perforating branches of the middle cerebral artery. A microanatomical study. $J$ Neurosurg 62: 261-268.

12. Rana KS, Behera MK, Adhikari KM (2006) Ischemic stroke following mild head injury is it the cause. Indian Pediatr 43: 994-997.

13. Morris CR (2008) Mechanisms of vasculopathy in sickle cell disease and thalassemia. Hematology Am Soc Hematol Educ Program.2008:177-185.

14. Golden GS (1985) Stroke syndromes in childhood. Neurol Clin 3: 59-75.

15. Kato GJ (2008) Novel small molecule therapeutics for sickle cell disease: nitric oxide, carbon monoxide, nitrite and apoilipoprotein A-I. Hematology Am Soc Hematol Educ Program:186-192. 